UDC 661.73

\title{
SYNTHESIS HYDROXYETHYL IMIDAZOLINES OF NATURE PETROLEUM ACIDS UNDER THE INFLUENCE OF CAVITATION EFFECT
}

\author{
X.H.Kasamanli \\ Canca State University \\ v_ramin@bk.ru \\ Received 18.04.2020 \\ Accepted 07.07.2020
}

\begin{abstract}
The synthesis hydroxyethyl imidazolines of NPA under the influence of ultrasound took place under the influence of the cavitation effect created by ultrasound. It became clear from the results that by applying the cavitation effect of ultrasound to the classical method of synthesis of imidazolines, it is possible to reduce the synthesis time by 2-5 times compared to other synthesis methods, obtaining imidazolines with a yield of $92-97 \%$. The synthesis time for this synthesis was 4 hours, the molar ratio of acid and amine was 1:1, the amplitude of the ultrasonic processor was $55 \%$ and the final temperature was $200^{\circ} \mathrm{C}$.
\end{abstract}

Keywords: imidazoline, cavitation effect, nature petroleum acids, ultrasound amplitude, solvent.

doi:

\section{Introduction}

Imidazolines refert to the classification of cation-type surfactants [6]. It makes imidazolines and their derivates to be applied in different industrial fields of a wide range. At present, imidazolines are applied as inhibitor, dispersant, emulsifying agent, antistatic compounds, bleaching activators, biologically active compounds and etc. in the at the refinery, as weaving dye, oil production and other industrial areas [1].

Given the wide range of applications of imidazolines, many methods for their synthesis have been developed. Among these synthesis methods, the most common is the classical chemical synthesis method based on the thermal action of imidazolines on acids and amines $[2,3,7]$.
However, like many organic synthesis methods of imidazolines have a number of shortcomings, such as large synthesis time, low yield and selectivity $[4,5]$. For this reason, research to address the shortcomings of the above synthesis methods is one of the most pressing issues facing organic synthesis today $[3,5,6]$.

\section{Experimental part}

In the present work, the process of synthesis of hydroxyethyl imidazolines (HEIm) of natural petroleum acids (NPA) was studied and optimal conditions were determined.

The general equation for the synthesis of hydroxyethyl imidazolines of natural petroleum acids is following:

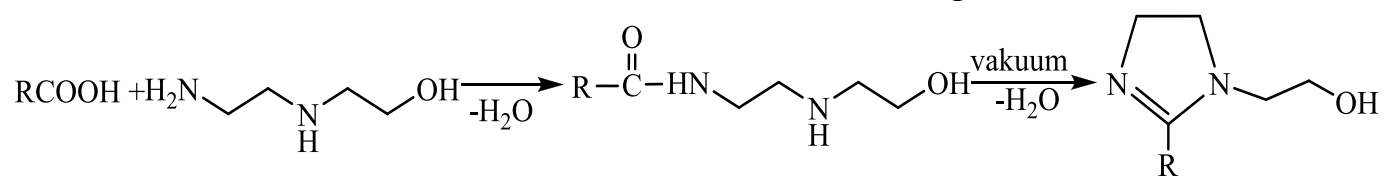

The factors influencing the synthesis process and yield in this synthesis method are as follows: ultrasound amplitude, nature and amount of the solvent; mole ratio of acid and amine.

To study the effect of the amplitude of ultrasound on the process synthesis were carried out at different values of amplitude: 40, 50, 55, $60 \%$ etc., respectively. In this case, the synthesis processes were carried out in $o$-xylene $\left(\mathrm{V}_{\mathrm{NPA}}: \mathrm{V} o\right.$-xylene $\left.=1: 1.5\right)$ in a mixture of NPA and hydroxyethylethylene diamine (HEEDA) in a ratio of 1:1.5 moles. A graphical description on the results obtained is shown in Figure 1.

As can be seen from the graph curves (Figure 1) under the amplitude value is increase from $40 \%$ to $55 \%$, yield of imidazoline increases from 87.0 to $90.3 \%$, respectively. However, at values above $55 \%$ of the ultrasound amplitude, no significant change of yield is observed. 


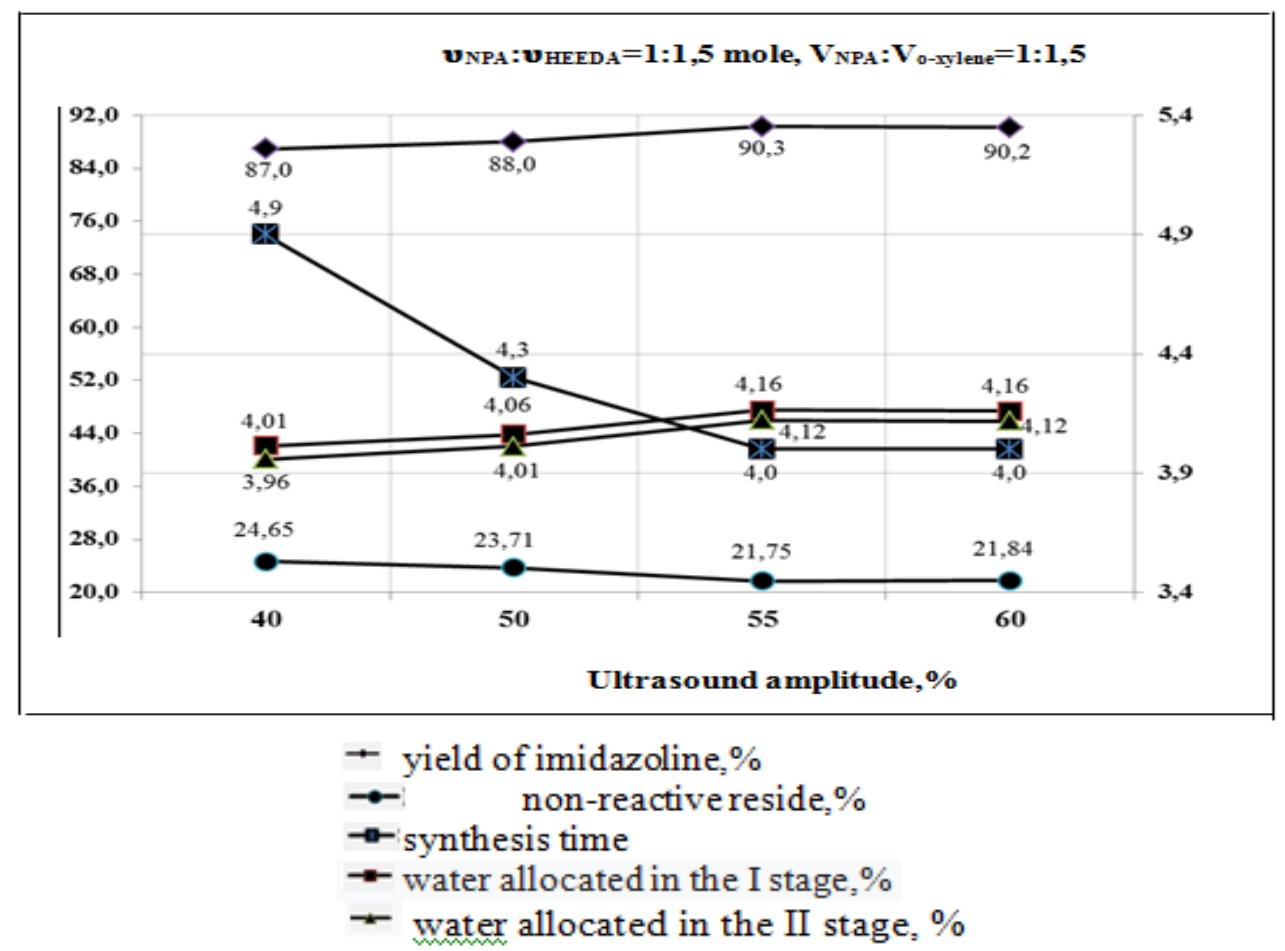

Fig. 1. Effect of ultrasound amplitude on imidazoline yield and synthesis time.

On the other hand as can be seen from the graph curves, when the amplitude of the ultrasound is increased from $40 \%$ to $55 \%$, the synthesis time decreases from 4.9 to 4.0 hours. At the same time, a decrease in non-reactive residue was observed. In the course decrease of non-reactive residue, the water released in the I and II stages increases. Based on this, it should be noted that at $55 \%$ of the amplitude, the synthesis time is shorter (4.0 hours) and the yield (90.3\%) is higher.

The effect of the nature of the solvent on determining the optimal synthesis conditions of hydroxyethyl imidazolines was investigated. For this purpose, syntheses of acids and various solvents ( $o$-xylene, $p$-xylene, $m$-xylene, toluene) in the ratio of $1: 1.5$ were carried out. In this case, the amplitude of the ultrasound was $60 \%$, and the acid and amine were taken in a ratio of 1:1.5 mol. The results are shown in Figure 2.

As can be seen from the graphical results, the yield of synthesis is relatively high in the the $o$-xylene environment $(90.3 \%)$, almost the same in the $m$-xylene and toluene environment (89.3 and 89.5\%), and thr lowest in the $p$-xylene environment $(88.1 \%)$. Besides the effect of the nature of the solvent on the synthesis process was observed. The results showed that the synthesis in $o$-xylene environment was completed within 4.0 hours, while the synthesis in $m$ xylene, $p$-xylene and toluene was completed in 4.3-4.4 hours.

On the other hand, it was found that the amount of water released in stages I (based on the taken amidoamine) and II (formation of imidazolines ring) in the $o$-xylene environment was relatively high, and accordingly, the unrected residue was lower. The amount of water released from the solvents in the $p$-xylene environment in stages I and II was minimal, and accordingly the non-reactive residue was relatively high. Based on these results, it can be noted that it would be more expedient to carry out the process of synthesis of NPA hydroxyethyl imidazolines in an $o$-xylene environment.

Figure 3 graphically shows the effect of the amount of $o$-xylene on the yield and duration of synthesis.

In the synthesis of hydroxyethyl imidazolines, the yield increases by about $3 \%$, when the volume ratio of NPA and $o$-xylene is increased from $1: 1.5$ to $1: 2.0$. At the same times, the results show that there is no significant change in the yield of the synthesis process in the ratios of $1: 2.5$ and 1:3.0 volumes of NPA and $o$-xylene. 


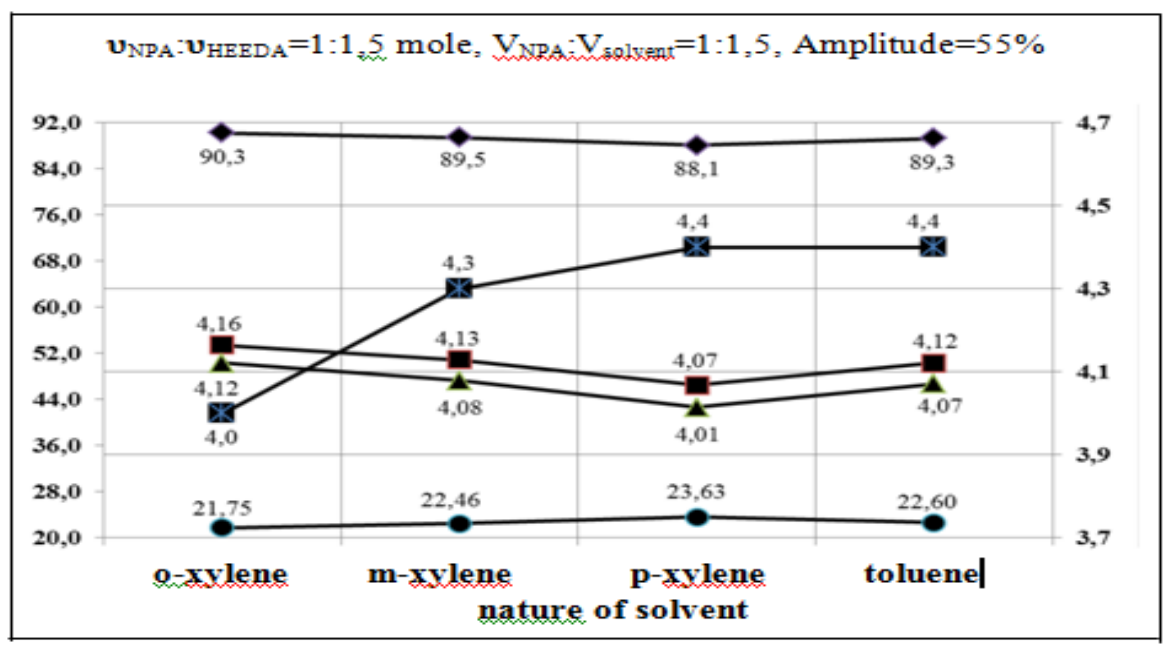

Fig. 2. The effect of the nature of the solvent on the yield of imidazoline and reaction time.

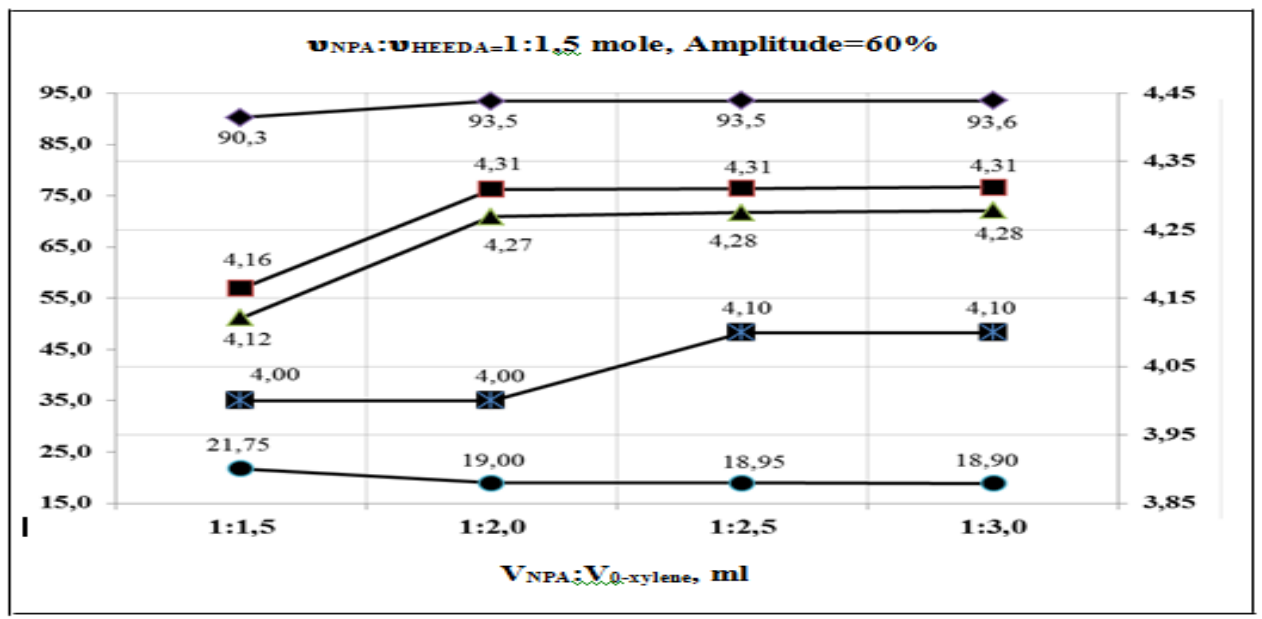

Fig. 3. The effect of the amount of solvent on the yield of imidazoline and synthesis time.

On the other hand, no significant change in the effect of changes in the volume of $o$ xylene on the synthesis process üas observed. It was found that when increased the volume ratio of NPA and $o$-xylene from 1:2.0 to 1:3.0, the synthesis time varies in the range of 4.0-4.1.

The results show that when the volume ratio of NPA and o-xylene is increased from $1: 1.5$ to $1: 2.0$ the amount of water released in stages I and II increase, while the amount of non-reactive residue decreases. Thus, during the synthesis of NPA and $o$-xylene in the ratio of $1: 1.5$ the water released in stages I and II is $4.16 \%$ and $4.12 \%$, while the unreacted residue is $21.75 \%$, the volume is $1: 2.0$. During the synthesis, the water released in the first and second stages increased to $4.31 \%$ and $4.27 \%$, and the unreacted residue decreased to $19.00 \%$.
Despite this, the optimal synthesis conditions were observed in a 1:2.0 volume ratio of NPA and o-xylene.

Based on the results obtained, it can be noted that for this synthesis method it is expedient to accept the optimal volume ratio of NPA and $o$-xylene 1:2.0.

Figure 4 shows the effect of the molar ratio of starting materials on the yield and duration of synthesis. As can be seen from the graph, when the molar ratio of NPA and HEEDA varies from $1: 1.0$ to $1: 1.5$, the synthesis yield varies between $93.5-93.6 \%$.

This interval does not reflect a significant change and therefore allows the optimal molecular ratio of NPA and HEEDA to be 1:1,0 for this synthesis method. 


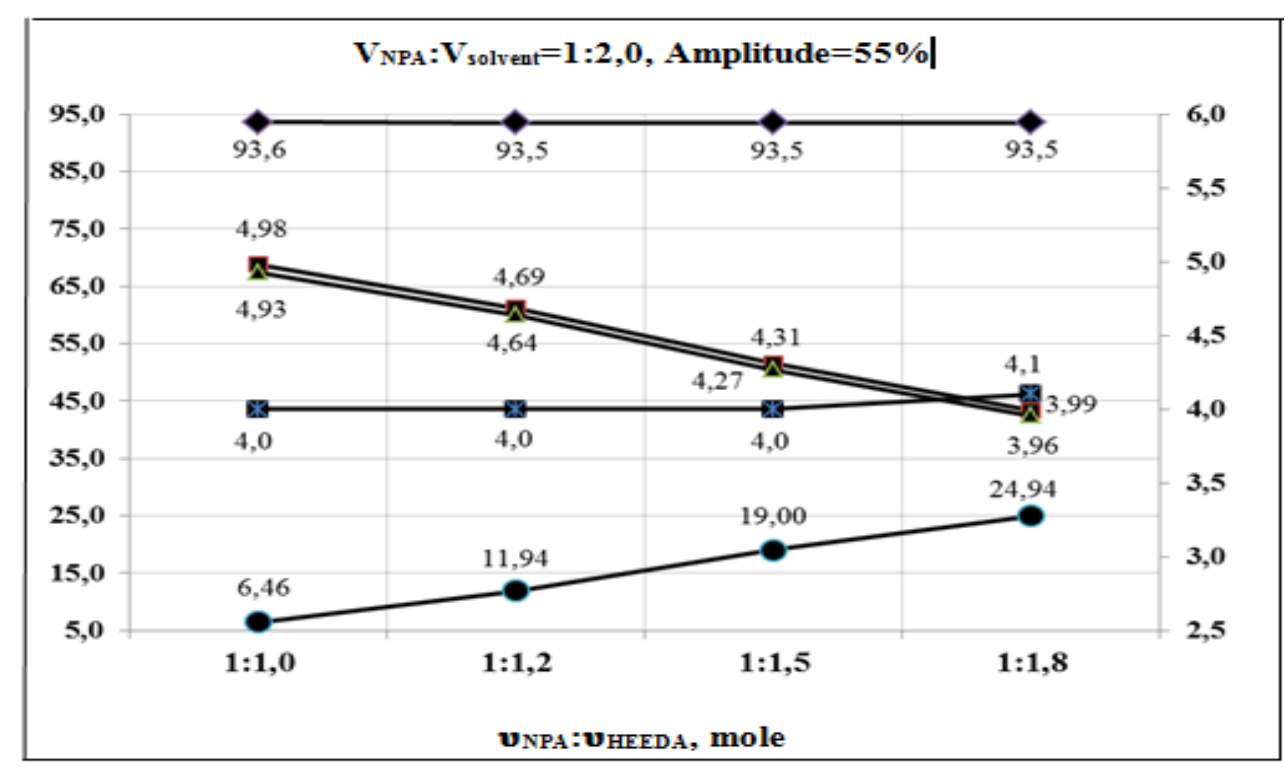

Fig. 4. The effect of molar ratio of starting materials on the yield of imidazoline and synthesis time.

As for the effect of the mole ratio of the starting materials on the synthesis process, no significant change is observed. Synthesis in selected molar ratios was completed in 4.0-4.1 hours.

\section{Results and discussion}

Table 1 show the yield and synthesis time of hydroxyethyl imidazolines synthesized under optimal conditions.
As can be seen from Table 1, to obtain high yield hydroxyethyl imidazolines for NPA, the ultrasound amplitude should be $55 \%$ and the acid and amine in a 1:1 mole ratio. In this case, the synthesis time is 4 hours and the yield of imidazolines varies in the range of $92.5-93.7 \%$.

Table 2 shows the material balance of the synthesis of hydroxyethyl imidazolines.

Table 1. Optimal conditions for the synthesis of hydroxyethyl imidazolines by NPA

\begin{tabular}{|c|c|c|c|c|c|}
\hline Symbol of imidazoline & $v_{\text {acid }}: v_{\text {HEEDA }}$ & $\begin{array}{c}\text { Ultrasound of } \\
\text { amplitude }\end{array}$ & $\begin{array}{c}\tau, \\
\text { Hour }\end{array}$ & $\begin{array}{l}\tau_{\text {end }} \\
{ }^{0} \mathrm{C}\end{array}$ & Yield, \% \\
\hline NPA I fr. HEIm & $1: 1.0$ & 55 & 4.0 & 200 & 93.58 \\
\hline NPA II fr. HEIm & $1: 1.0$ & 55 & 4.0 & 200 & 92.83 \\
\hline NPA IIIfr. HEIm & $1: 1.0$ & 55 & 4.0 & 200 & 92.68 \\
\hline NPA common fr. HEIm & $1: 1.0$ & 55 & 4.0 & 200 & 92.91 \\
\hline
\end{tabular}

Table 2. Material balance of the synthesis of hydroxyethyl imidazolines of NPA

\begin{tabular}{|c|c|c|c|c|c|c|c|c|}
\hline \multirow{2}{*}{$\begin{array}{l}\text { Symbol } \\
\text { of imidazoline }\end{array}$} & \multirow{2}{*}{$\begin{array}{l}\text { NPA, } \\
\text { g } \\
(\mathrm{mol})\end{array}$} & \multirow{2}{*}{$\begin{array}{c}\text { DETA, } \\
\text { g } \\
(\mathrm{mol})\end{array}$} & \multicolumn{2}{|c|}{$\begin{array}{c}\text { Mass of imidazoline } \\
\mathrm{g}(\%)\end{array}$} & \multicolumn{2}{|c|}{$\begin{array}{c}\text { *Water } \\
\mathrm{g}(\%)\end{array}$} & \multirow{2}{*}{$\begin{array}{l}\text { Residue }{ }^{*}, \\
\text { g }(\%)\end{array}$} & \multirow{2}{*}{$\begin{array}{l}\text { Yield, } \\
\%\end{array}$} \\
\hline & & & theoretical & practical & theoretical & practical & & \\
\hline $\begin{array}{l}\text { NPA I fr. } \\
\text { HEIm }\end{array}$ & $\begin{array}{c}47.02 \\
(0.2)\end{array}$ & $\begin{array}{c}20.62 \\
(0.2)\end{array}$ & 60.44 & $\begin{array}{c}56.30 \\
(83.23) \\
\end{array}$ & 7.20 & $\begin{array}{c}6.69 \\
(9.89)\end{array}$ & $\begin{array}{l}4.65 \\
(6.88)\end{array}$ & 93.1 \\
\hline $\begin{array}{l}\text { NPA II fr. } \\
\text { HEIm }\end{array}$ & $\begin{array}{c}50.24 \\
(0.2)\end{array}$ & $\begin{array}{l}20.62 \\
(0.2)\end{array}$ & 63.66 & $\begin{array}{c}59.50 \\
(83.96)\end{array}$ & 7.20 & $\begin{array}{c}6.71 \\
(9.48)\end{array}$ & $\begin{array}{l}4.65 \\
(6.56)\end{array}$ & 93.5 \\
\hline $\begin{array}{l}\text { NPA III fr. } \\
\text { HEIm }\end{array}$ & $\begin{array}{l}53.08 \\
(0.2)\end{array}$ & $\begin{array}{l}20.62 \\
(0.2)\end{array}$ & 67.30 & $\begin{array}{c}63.08 \\
(84.67)\end{array}$ & 7.20 & $\begin{array}{c}6.73 \\
(9.04)\end{array}$ & $\begin{array}{c}4.69 \\
(6.29)\end{array}$ & 93.7 \\
\hline $\begin{array}{l}\text { NPA common fr. } \\
\text { HEIm }\end{array}$ & $\begin{array}{c}49.08 \\
(0.2) \\
\end{array}$ & $\begin{array}{l}20.62 \\
(0.2)\end{array}$ & 62.50 & $\begin{array}{c}57.79 \\
(82.91) \\
\end{array}$ & 7.20 & $\begin{array}{c}6.64 \\
(9.53) \\
\end{array}$ & $\begin{array}{l}5.27 \\
(7.56)\end{array}$ & 92.5 \\
\hline
\end{tabular}

${ }^{*}$ Water - it is the total mass of water released in stages I and II;

*** residue - it is assumed that it consists of amines and acids remaining after the synthesis process. 
Table 3. Physic-chemical properties of imidazolines synthesized under optimal conditions

\begin{tabular}{|c|c|c|c|c|c|}
\hline Symbol of imidazoline & $\begin{array}{c}\text { Aggregate } \\
\text { condition }\end{array}$ & Color & $\mathrm{kg} / \mathrm{m}^{3}$ & $\begin{array}{c}\text { Amine number } \\
\text { mq KOH/q imidazoline }\end{array}$ & $\begin{array}{c}\text { Acid number } \\
\text { moH/q imidazoline }\end{array}$ \\
\hline NPA I fr. HEIm & viscous liquid & dark brown & 980 & 79 & 1.18 \\
\hline NPA II fr. HEIm & viscous liquid & dark brown & 1030 & 91 & 1.22 \\
\hline NPA IIIfr. HEIm & viscous liquid & dark brown & 1020 & 89 & 1.24 \\
\hline NPA common fr. HEIm & viscous liquid & dark brown & 1030 & 81 & 1.21 \\
\hline
\end{tabular}

Table 3 shows the physicochemical properties of hydroxyethyl imidazolines of different fractions of natural petroleum acids synthesized under optimal conditions. As can be seen from Table 3, regardless of the boiling temperatures of the NPA fractions used, the hydroxyethyl imidazolines obtained are viscous dark brown liquids, with densities ranging from 980 to $1030 \mathrm{~kg} / \mathrm{m}^{3}$ and amine number ranging from 79 to $89 \mathrm{mg} \mathrm{KOH} / \mathrm{g}$.

The structures of hydroxyethyl imidazolines synthesized under optimal conditions have been proven by ${ }^{1} \mathrm{H},{ }^{13} \mathrm{C}$ NMR and IR spectroscopy.

\section{References}

1. Abbasov V.M., Məmmədova T.A., Kəsəmənli X.H., Təbii neft turşularının imidazolinlərinin dizel yanacağına aşqar kimi tətbiqi. SOCAR $1^{\text {st }}$ İntern. Scientific Conference of young scientists and specialists, Baku 2014. 15-16 october, S. 305.

2. Bistline R.G., Hampson J.W., Linfield W.M. Synthesis and prorerties of fatty imidazoline and their
N-(2-Aminoethyl) derivatives. JAOCS. 2008. V. 80. No 4. P. 823-828.

3. Bondareva and S.O., Murinov Yu.I. Synthesis and physicochemical properties of 1-(2-Alkylamidoethyl)-2-alkyl-2-imidazolines based on $\alpha, \alpha^{\prime}$-branched carboxylic Acids. Russian J. General Chem. 2013. V. 83. No. 2. P. 373-378.

4. Guo-hao C., Jing-mao Z., Corrosion inhibition of imidazoline derivates with benzene rings on mild steel in $\mathrm{CO}_{2}$-saturated brine solution. Chem. Res. Chinese Universities. 2012. V. 28. No 4. P. 691-695.

5. Shisedo A.N. Fatty imidazoline: chemistry, synthesis, properties and their industrial applications. J. oleo Science. 2006. V. 55. No 7. P. 319-329.

6. Абрамзон А.А., Зайченко Л.П., Файнгольд С.И. Поверхностно-активные вещества. Синтез, анализ, свойства, применение: учебное пособие для вузов. Л.: Химия. 1988. 200 с.

7. Hamirin K., Nakasato S., Masni Ab.R. Imidazoline amphoteric surfactants from palm and palm kernel fatty acids. ELAEİS. 1991. V. 3. No 1. P. 294-301.

8. Iftikhar A., Mohamed N., Abubaker K. The nitrogenous corrosion inhibitors used in petroleum production. Intern. J. pharmaceutical and chemical sci. 2014. V. 3. No 1. P. 255-259.

\title{
KAVITASIYA EFFEKTININ TəSİİ İLə TəBIII NEFT TURŞULARININ HIDROKSIETIL IMIDAZOLINLORININ SINTEZi
}

\begin{abstract}
X.H.Kəsəmənli
Ultrasəsin təsiri ilə TNT-nın hidroksietil imidazolinlərin sintezi, ultrasəsin yaratdığı kavitasiya effektinin təsiri altında baş vermişdir. Alınan nəticələrdən aydın olmuşdur ki, ultrasəsin yaratdığı kavitasiya effektini imidazolinlərin klassik sintez metoduna tətbiq etməklə sintez müddətinin digər sintez metodları ilə müqayisədə $2-5$ dəfə azaldılmasına, imidazolinlərin 92-97\%-lə çıxımla alınmasına nail olmaq olar. Bu sintez üçün sintez müddəti 4 saat, turşu və aminin mol nisbəti 1:1, ultrasəs prosessorunun amplitudasının $55 \%$, son temperatur $200^{\circ} \mathrm{C}$ müəyyən olunmuşdur.
\end{abstract}

Açar sözlor: imidazolin, kavitasiya effekti, təbii neft turşuları, ultrasasin amplitudası, həlledici.

\section{СИНТЕЗ ГИДРОКСИЭТИЛ ИМИДАЗОЛИНОВ НАТУРАЛЬНЫХ НЕФТЯНЫХ КИСЛОТ ПРИ ЭФФЕКТЕ КАВИТАЦИИ}

\section{Х.Г.Касаманли}

Синтез гидроксилэтиловых имидазолинов нефтяных кислот происходило под влиянием кавитационного эффекта создаваемого ультразвука. Из полученных результатов стало ясно что, применяя кавитационный эффект ультразвука к классическому методу синтеза имидазолинов, можно сократить время синтеза в 2-5 раза по сравнению с другими методами синтеза, получая имидазолины с выходом 92-97\%. Время синтеза для этого процесса синтеза составляло 4 часа, молярное соотношение кислоты и амина составляло 1:1, амплитуда ультразвука $55 \%$ и конечная температура составляла $200^{\circ} \mathrm{C}$.

Ключевые слова: имдазолин, кавитаџионный эффект, натуральные нефтяные кислоты, амплитуда ультразвука, растворитель. 